\title{
Evidence that the Lateral Septum is Involved in the Antidepressant-Like Effects of the Vasopressin $V_{\mathrm{lb}}$ Receptor Antagonist, SSR I494I5
}

\author{
Jeanne Stemmelin', Ludovit Lukovic ${ }^{2}$, Nicolas Salome' and Guy Griebel*,' \\ 'Sanofi-Synthélabo Research, Department of Psychopharmacology, CNS Research Department, Bagneux, France; '2Sanofi-Synthélabo Research, \\ Department of Biochemistry, Exploratory Research Department, Strasbourg, France
}

\begin{abstract}
Previous experiments with the first selective nonpeptide vasopressin $V_{\mathrm{Ib}}$ receptor antagonist SSRI494I5 ((2S, 4R)-I-[5-chloro-I - [(2,4dimethoxyphenyl)sulfonyl]-3-(2-methoxyphenyl)-2-oxo-2,3-dihydro- I H-indol-3-yl]-4-hydroxy-N,N-dimethyl-2-pyrrolidinecarboxamide) have shown that the drug elicits anxiolytic- and antidepressant-like effects following systemic administration. Extrahypothalamic $V_{\mathrm{Ib}}$ receptors have been suggested to be involved in these effects as evidenced by the findings that hypophysectomized rats were still sensitive to the antistress action of SSR I 494 I5. The first objective of the present work aimed at locating $\bigvee_{\text {Ib }}$ receptors in the rat limbic brain using anti- $\mathrm{V}_{\mathrm{Ib}}$ receptor immunohistochemistry. The immunolabeling revealed high densities of $\mathrm{V}_{\mathrm{Ib}}$ receptors in the lateral septum, the amygdala, the bed nucleus of the stria terminalis, the hippocampal formation, and in several cortical areas. Since the lateral septum is well known to participate in the modulation of emotional processes, the second objective of this study went on to evaluate the behavioral effects of an infusion of SSRI494I5 into the lateral septum and to determine whether its behavioral effects are mediated by this structure. Animals were tested in models classically used for the screening of anxiolytics (ie the punished drinking and elevated plusmaze tests) and antidepressants (ie the forced-swimming test). Bilateral intraseptal infusion of SSRI494I5 (I0 and I00 ng) produced a decrease in immobility time in the forced-swimming test, indicating antidepressant-like effects. In contrast, the behavior of rats in the punished drinking procedure or in the elevated plus-maze test was not modified by intraseptal infusion of SSRI494I5. These findings suggest that $V_{\text {Ib }}$ receptors located in the lateral septum participate in the antidepressant- but not the anxiolytic-like action of SSR I494 I 5 in rats.
\end{abstract}

Neuropsychopharmacology (2005) 30, 35-42, advance online publication, 15 September 2004; .doi:I 0. I038/sj.npp. I 300562

Keywords: vasopressin; anxiolytic; antidepressant; lateral septum; $V_{\text {Ib }}$ receptor; SSR I 494I 5

\section{INTRODUCTION}

Vasopressin is a nonapeptide that is synthesized in hypothalamic nuclei. This peptide is critical for the regulation of the activity of the hypothalamo-pituitaryadrenocortical axis representing a major component of the stress response. Vasopressin promotes pituitary adrenocorticotropin release through its ability to potentiate the stimulatory effects of corticotropin-releasing factor (Aguilera and Rabadan-Diehl, 2000). Among the two $G_{q / 11^{-}}$ coupled vasopressin receptors $\left(\mathrm{V}_{1 \mathrm{a}}\right.$ and $\left.\mathrm{V}_{1 \mathrm{~b}}\right)$ found in the brain, the $V_{1 b}$ subtype mediates the pituitary actions of vasopressin. Although there is experimental evidence that

\footnotetext{
*Correspondence: Dr G Griebel, Sanofi-Synthelabo Research, Department of Psychopharmacology, 31 avenue Paul Vaillant-Couturier, 92220 Bagneux, France, Tel: + 33 |45362470, Fax: + 33 |45362070, E-mail: guy.griebel@sanofi-synthelabo.com

Received I April 2004; revised 3 August 2004; accepted 4 August 2004 Online publication: 6 August 2004 at http://www.acnp.org/citations/ Npp08060404 I5 I/default.pdf
}

the expression of $\mathrm{V}_{1 \mathrm{~b}}$ receptor mRNA increases after chronic stress exposure (Rabadan-Diehl et al, 1997), the role of $\mathrm{V}_{1 \mathrm{~b}}$ receptors in the regulation of the stress response is poorly understood. Recently, the first selective nonpeptide antagonist of the $\mathrm{V}_{1 \mathrm{~b}}$ receptor, SSR149415 $((2 S, 4 R)-1$ [5-chloro-1-[(2,4-dimethoxyphenyl)sulfonyl]-3-(2-methoxyphenyl)-2-oxo-2,3-dihydro-1 $H$-indol-3-yl]-4-hydroxy- $N, N$ -dimethyl-2-pyrrolidinecarboxamide), was described (Serradeil-Le Gal et al, 2002). Behavioral studies showed that SSR149415 is endowed with anxiolytic- and antidepressantlike properties (Griebel et al, 2002, 2003). For example, the drug displayed anxiolytic-like effects in the punished drinking and elevated plus-maze tests in rats. Furthermore, SSR149415 elicited antidepressant-like effects in the forcedswimming test in rats. In this latter test, hypophysectomy did not affect the effect of SSR149415, suggesting that extrahypothalamic $\mathrm{V}_{1 \mathrm{~b}}$ receptors may be involved in the antidepressant-like action of SSR149415. Vasopressincontaining neurons have been described in the limbic brain areas such as the medial amygdala and the bed 
nucleus of the stria terminalis (Caffe et al, 1987; De Vries and Buijs, 1983), which both project to the lateral septum. This latter structure has been shown to be involved in the expression of anxiety-related behaviors such as those elicited in conflict procedures or exploration tests (Treit and Menard, 2000; Yadin et al, 1993). For example, lesion studies have demonstrated that the removal of the entire septum produces antianxiety effects in the elevated plusmaze test (Treit and Pesold, 1990). As a consequence, it has been suggested that the inhibition of the activity of the septum could reduce fear. Microinjection studies have also shown that the infusion of the benzodiazepine midazolam into the lateral septum (but not the medial septum) increased open arm activity in the elevated plus-maze and decreased burying behavior in the shock-probe test (Pesold and Treit, 1994), suggesting that the reduction in septal activity through the facilitation of the inhibitory activity of GABA produced an anxiolytic-like effect. Similarly, the participation of the lateral septum in the modulation of behavior in models sensitive to antidepressants has also been documented (Contreras et al, 1995). These authors showed that early lesions of the lateral septum altered both the duration of immobility in the forced-swim test and the response to antidepressants when rats were tested several weeks later. Furthermore, intraseptal infusions of the reference antidepressant imipramine produced antidepressant-like effects in the forced-swimming test in rats (Estrada-Camarena et al, 2002), as is the case with 5- $\mathrm{HT}_{1 \mathrm{~A}}$ receptor ligands (Schreiber and De Vry, 1993), confirming that the lateral septum mediates the behavioral effects of antidepressants. Concerning vasopressinergic tone, it has also been reported that the release of the peptide in the septum modulates social memory (Dantzer et al, 1988), aggressive (Everts et al, 1997), and anxiety-related behaviors in rats (Liebsch et al, 1996). Furthermore, these authors and others (Landgraf et al, 1995) have shown that the intraseptal application of nonselective $V_{1}$ receptor antagonists or $V_{1 a}$ receptor antisense produces anxiolytic-like effects in the elevated plus-maze in rats. It was also demonstrated that swim stress enhances the septal release of vasopressin (Ebner et al, 1999), suggesting a close relationship between vasopressin released in the septum and stress-coping strategies. Using anti- $\mathrm{V}_{1 \mathrm{~b}}$ receptor immunohistochemistry, the presence of $\mathrm{V}_{1 \mathrm{~b}}$ receptors was demonstrated in various regions of the rat brain (Hernando et al, 2001), including the olfactory system, the basal forebrain and basal ganglia, the hippocampal formation, some amygdaloid, thalamic, and hypothalamic nuclei, some cortical areas, and the cerebellum. Although $\mathrm{V}_{1 \mathrm{~b}}$ mRNAs were previously located in the rat septal area using RT-PCR (Lolait et al, 1995), data concerning the localization of the protein in the lateral septum using selective anti- $\mathrm{V}_{1 \mathrm{~b}} \mathrm{R}$ antibody are still lacking. In this context, the first objective of the present work was to study the immunohistochemical localization of $\mathrm{V}_{1 \mathrm{~b}}$ receptors in the rat brain using a new and specific anti$\mathrm{V}_{1 \mathrm{~b}} \mathrm{R}$ antibody. In order to confirm that extrahypothalamic $\mathrm{V}_{1 \mathrm{~b}}$ receptors may be involved in the antistress action of SSR149415, the second objective of this study was to examine the behavioral effects of intraseptal infusion of the $\mathrm{V}_{1 \mathrm{~b}}$ receptor antagonist using the punished drinking and elevated plus-maze tests, two tests classically used to monitor anxiolytic-like drug effects, and the forcedswimming test, a test generally used for the screening of antidepressants.

\section{MATERIALS AND METHODS}

Male Sprague-Dawley rats (200-250 g, Iffa Credo, Les Oncins, France) housed in groups of five upon arrival were used. After surgery, they were housed in single cages $(20 \times 30 \times 18 \mathrm{~cm})$ and maintained under a 12:12 LD cycle (lights on at 0700). Food and water was available ad libitum, except the days preceding the punished drinking test for which a 48 -h water deprivation period was required. The behavioral experiments were performed between 0900 and 1500. All experimental procedures described herein were approved by the Animal care and Use Committee of SanofiSynthelabo Recherche and fully comply with French legislation on research involving laboratory animals.

\section{Anti $\mathrm{V}_{\mathbf{1 b}}-\mathrm{R}$ Immunohistochemistry}

Biological material. Five rats were anesthetized with pentobarbital (Ceva Santé Animal, Libourne, France, $60 \mathrm{mg} / \mathrm{kg}$, i.p.), then perfused intracardiacally with heparinized-phosphate-buffered saline (PBS, $0.01 \mathrm{M} ; \mathrm{pH} 7.4$ ), and paraformaldehyde 4\% (Sigma, St Louis, MO, USA). Brains were removed from the skull and postfixed overnight in paraformaldehyde $4 \%$ at $4{ }^{\circ} \mathrm{C}$. The dehydration of the brains was performed with gradual concentrations of alcohol. Brains were subsequently embedded in paraffin-wax (Paraplast Plus, SPI, West Chester, PA, USA) blocks.

Immunohistochemical labeling. Tissue sections $(5 \mu \mathrm{m})$ were mounted on electrostatically treated slides (SuperFrost Plus, Menzel-Glaser, Freiburg, Germany) and were processed for antigen retrieval, which includes deparaffinization and rehydration. Briefly, the slides were immersed in the Trilogy reagent (diluted 1:20 with distilled water) and heated to $90^{\circ} \mathrm{C}$ in a PC-controlled microwave oven (MicroMED BASIC, Milestone, Italy) for $20 \mathrm{~min}$ and left for the next $10 \mathrm{~min}$ in the microwave without heating. Slides were subsequently reloaded into the second container with hot Trilogy and kept in for $10 \mathrm{~min}$ at bench. The slides were then washed three times for $5 \mathrm{~min}$ with PBS ( $\mathrm{pH}$ 7.4). For immunohistochemical detection of the $\mathrm{V}_{1 \mathrm{~b}}$ receptor, sections were incubated with $3 \% \mathrm{H}_{2} \mathrm{O}_{2}$ diluted in PBS for 15 min. After washing in PBS containing $0.05 \%$ Tween 20 to neutralize nonspecific binding sites, the sections were covered with PBS containing 5\% normal goat serum (NGS) and $0.3 \%$ Triton $\mathrm{X}-100$ for $20 \mathrm{~min}$ at room temperature (RT), then drained and incubated for $120 \mathrm{~min}$ at $\mathrm{RT}$ with rabbit anti-rat $\mathrm{V}_{1 \mathrm{~b}}$ receptor antibody diluted (1:250) in PBS containing 1.5\% NGS and 0.1\% Triton X-100 (antibody diluting buffer). Subsequently, the slides were covered with the PicTure ${ }^{\mathrm{TM}}$-Plus KIT HRP (horseradish peroxidase-conjugated polymer coupled to goat anti-rabbit IgG antibodies) for $30 \mathrm{~min}$ at RT. Staining was completed by incubation with the peroxidase substrate diaminobenzidine (DAB) (Liquid DAB-Plus Substrate Kit, Zymed Laboratories Inc., San Francisco, CA, USA) for 8 min at RT. Sections were counter-stained with hematoxylin (Zymed Laboratories 
Inc., San Francisco, CA, USA), a nuclear marker, then mounted with Entellan (Merck, Darmstadt, Germany) and coverslipped.

Slides were analyzed by transmission microscopy using a Leica microscope (Leitz DMREB, Bannockburn, IL, USA) equipped with a video CCD camera (Sony DCX-930, New York, NY, USA). Sections taken at different levels of the rat brain (according to the rat brain atlas of Paxinos and Watson, 1998) were used to index the immunoreactive signal of $\mathrm{V}_{1 \mathrm{~b}} \mathrm{R} ;+++,++$, or + was used to denote strong, moderate, or low but positive signals, respectively. Micrographs were made using the MetaMorph 4.6r6 image analysis system (Universal Imaging Corporation ${ }^{\mathrm{TM}}$, Downingtown, PA, USA).

Control experiment. The specificity of the polyclonal rabbit anti-rat $V_{1 b}$ receptor antibody previously used in the literature (Hurbin et al, 2002; Folny et al, 2003) was confirmed in the present study: (1) by staining in the absence of the primary antibody, replaced by buffer dilution (negative control), and (2) by preabsorption of the rabbit anti-rat $\mathrm{V}_{1 \mathrm{~b}}$ antibody with the rat immunogenic peptide sequence $(10,30$, and $100 \mu \mathrm{g} / \mathrm{ml})$. Rabbit anti-rat $\mathrm{V}_{1 \mathrm{~b}}$ receptor antibody diluted 1:250 was incubated for $30 \mathrm{~min}$ at $37^{\circ} \mathrm{C}$ with rat peptide antigens $(10,30$, and $100 \mu \mathrm{g} / \mathrm{ml})$. The primary antibody not mixed with any of the peptides was subjected to the same procedure as the antibody preabsorbed with peptide antigen.

Chemicals and antibody. The Trilogy reagent for tissue deparaffinization and antigen retrieval was from Cell Marque (Hot Springs, AR, USA). The polyclonal anti- $\mathrm{V}_{1 \mathrm{~b}}$ receptor antibody and the corresponding blocking peptide were purchased from Alpha Diagnostic (San Antonio, TX, USA). NGS, Triton X-100, Tween 20 and $\mathrm{H}_{2} \mathrm{O}_{2}$ were from Sigma (St Louis, MO, USA). Antigen-antibody complex were detected by using PicTure ${ }^{\mathrm{TM}}$-KIT HRP (horseradish peroxidase conjugated, a stable amino-acid polymer, which carries goat anti-rabbit IgG antibodies) and Liquid DAB-Plus Substrate Kit (Zymed Laboratories Inc., San Francisco, CA, USA).

\section{Behavioral Experiments}

Surgical procedures. Rats were anesthetized with Zoletil (Virbac, Carros, France, $60 \mathrm{mg} / \mathrm{kg}$, i.p.) and placed in a stereotaxic frame (Kopf Instruments, Tujunga, CA, USA). Two guide cannulae consisting of stainless-steel tubings ( $26 \mathrm{G}, 12 \mathrm{~mm}$, Cooper, London, UK) were implanted in the lateral septum so as to position the tips at $1 \mathrm{~mm}$ above the medial part (coordinates from bregma: AP: 0.0 , ML: \pm 0.6 , $\mathrm{V}$ : -4.7 , according to the rat brain atlas of Paxinos and Watson, 1998). The guide cannulae were anchored to the skull with two jeweler screws (Plastic One, Ronaoke, VA, USA) and Paladur dental cement (Heraeus Kulzer, Hanau, Germany). After surgery, rats were allowed a 5-day recovering period. During this period, rats were handled twice before testing in order to verify that the cannulae obturators (A-M Systems, Carlsborg WA, USA) were kept in place. As a control experiment, guide cannulae were also implanted in the medial striatal region (AP: +0.3 , ML: $\pm 4.0, \mathrm{~V}:-4.8$ from bregma).

\section{Behavioral Testing}

The punished drinking test. The procedure was a modification of that described by Vogel et al (1971). Rats, water deprived for $48 \mathrm{~h}$ before testing, were placed in cages with a stainless-steel grid floor. Each cage contained a drinking tube connected to a $50-\mathrm{ml}$ burette filled with tap water. Trials were started when the rat's tongue had entered in contact with the drinking tube for the first time. An electric shock $(0.6 \mathrm{~mA}, 600 \mathrm{~ms})$ was delivered to the tongue every 20 licks. The number of shocks delivered was recorded during a 5-min period.

The elevated plus-maze test. The procedure is based on that described by Pellow et al (1985). The apparatus was made of polyvinylchloride. It was elevated to a height of $70 \mathrm{~cm}$ with two open $(50 \times 10)$ and two enclosed arms $(50 \times 10 \times 50)$ arranged so that the arms of the same type were opposite to each other. The apparatus was equipped with infrared beams and sensors capable of measuring activity in the different arms. The illumination intensity measured in the open arms was 30 lux. Rats were placed in the center of the maze for a free exploration period of $4 \mathrm{~min}$. Results were expressed as the mean ratio of time spent (or entries) in open arms to total time spent (or entries) in both open and closed arms and the mean number of entries in closed arms.

The forced-swimming test. The procedure was a modification of that described by Porsolt et al (1977). Animals were placed in an individual glass cylinder (diameter $17 \mathrm{~cm}$, height $40 \mathrm{~cm}$ ) containing water (height $24 \mathrm{~cm}, 22^{\circ} \mathrm{C}$ ). Two swimming sessions were conducted (an initial 6-min pretest followed the same day by a 6-min test). The duration of immobility (in s) was measured manually during the 6-min test by an experimenter who was unaware of the drug treatments.

\section{Drug Administration}

Every rat was tested consecutively in the three behavioral tests which were run in the following order: (1) the punished drinking test, (2) the elevated plus-maze test, and (3) the forced-swimming test. Each rat received the same treatment during the 3 consecutive days. At $10 \mathrm{~min}$ prior to testing, rats received a bilateral injection of the drug using stainless-steel microinjection cannulae (30 G Cooper, London, UK). The cannulae were connected by polyethylene tubings (Plastic One, Ronaoke, VA, USA) to microsyringes (Exmire, Ito Corporation, Fuji, Japan) mounted on a motorized pump (CMA, Solna, Sweden).

SSR149415, isomer(-), was synthesized by the Medicinal Chemistry Department of Sanofi-Synthelabo. It was prepared as a solution in physiological saline $0.9 \%$ containing DMSO 5\% (Sigma, Lyon, France) and Cremophor EL 5\% (Sigma, Lyon, France). Aliquots containing $1 \mu \mathrm{g} / 0.6 \mu \mathrm{l}$ SSR149415 were frozen and stored at $-20^{\circ} \mathrm{C}$. The following groups were constituted: control solution (saline $0.9 \%$ alone and a mixture of saline/DMSO/Cremophor) and SSR149415 (1, 10, and $100 \mathrm{ng}$ dissolved in saline/DMSO/Cremophor). All drugs were injected in the lateral septum at a volume of $0.3 \mu \mathrm{l} /$ side and at a rate of $0.2 \mu \mathrm{l} / \mathrm{min}$. Cannulae were left in 
place for an additional minute to avoid reflux of the drugs inside the guide cannulae. During the 2-min infusion, rats were slightly restrained by the experimenter. After injection, obturators were inserted and rats placed in their home cages. The same injection procedure was used for intrastriatal administration of SSR149415.

\section{Histology and Controls}

On the day after the completion of the last test, rats were killed with an overdose of pentobarbital (Virbac, Carros, France, $100 \mathrm{mg} / \mathrm{kg}$, i.p.), and brains were removed and frozen. Brain slices $(30 \mu \mathrm{m})$ were subsequently made using a cryostat and stained with cresyl violet. The placement of the microinjection cannulae was determined for each rat by an experimenter blind to the behavioral results. Cases where the tip of one or both cannulae was located outside the lateral septum were excluded for statistical analysis. Histological control for brain cannulae implanted in the medial striatum was carried out using the same procedure.

\section{Statistics}

All data were analyzed with one-factor analysis of variance (ANOVA). Significance was set at 0.05 . In cases of a significant main effect, post hoc comparisons were performed with a Dunnett test.

\section{RESULTS}

\section{Anti-V1 $1_{b} R$ Immunohistochemistry}

An overview of the rat brain regions where $V_{1 b}$ receptors were located using immunohistochemical detection is given in Table 1. There was no major difference in staining intensity between the different slices of the five rat brains. Moderate to intense cellular $\mathrm{V}_{1 \mathrm{~b}} \mathrm{R}$ immunoreactivity was observed in several limbic structures including the septum, the amygdala, the hippocampus, and the nucleus accumbens (see Figure 1). In the lateral septum, there was a moderate labeling of neuronal perikarya (dorsal, medial, and ventral parts, see Figure 1 for illustration). A similar positive immunoreactivity was observed in the posterolateral part of the bed nucleus of the stria terminalis (dorsal and ventral parts). The vertical and horizontal limb of the diagonal band of Broca as well as the medial septum presented low $\mathrm{V}_{1 \mathrm{~b}} \mathrm{R}$ immunoreactivity. $\mathrm{V}_{\mathrm{lb}}$ receptors were also found in the different amygdaloid nuclei. A moderate labeling was observed in the rostral part of the medial, basolateral, and central nuclei, but a more intense staining was observed in the caudal region. The nucleus accumbens (core) and the caudate putamen (medial region) showed moderate $\mathrm{V}_{1 \mathrm{~b}} \mathrm{R}$ immunoreactivity. In the nucleus accumbens (shell), the staining intensity was low. In cortical areas, $\mathrm{V}_{1 \mathrm{~b}} \mathrm{R}$ immunoreactivity was observed in the frontal and in the cingulate cortices. A weaker staining was observed in the parietal cortex. All fields of the Ammon's horn displayed $\mathrm{V}_{\mathrm{lb}} \mathrm{R}$ immunoreactivity at the rostrocaudal level. Moderate staining was observed in the stratum radiatum from $\mathrm{CA} 1$ and $\mathrm{CA} 2$ and the labeling was found to be particularly intense in the CA3 and CA4 fields. $\mathrm{V}_{1 \mathrm{~b}} \mathrm{R}$ immunoreactivity was also found in the dentate gyrus, subiculum and
Table I Distribution of the $V_{\mathrm{Ib}}$ Receptor Protein in Various Structures of the Rat Brain

\begin{tabular}{|c|c|}
\hline \multicolumn{2}{|l|}{ Cortex } \\
\hline Frontal cortex & ++ \\
\hline Cingulate cortex & + \\
\hline Entorhinal cortex & ++ \\
\hline Parietal cortex & + \\
\hline \multicolumn{2}{|l|}{ Basal ganglia } \\
\hline Nucleus accumbens shell & + \\
\hline Nucleus accumbens core & ++ \\
\hline Caudate/putamen & + \\
\hline \multicolumn{2}{|l|}{ Hippocampus } \\
\hline Dentate gyrus & ++ \\
\hline CAI & ++ \\
\hline CA2 & ++ \\
\hline CA3 & +++ \\
\hline CA4 & +++ \\
\hline Subiculum & ++ \\
\hline \multicolumn{2}{|l|}{ Basal forebrain } \\
\hline Lateral septum & ++ \\
\hline Medial septum & + \\
\hline Triangular septal nucleus & +++ \\
\hline Septofimbrial nucleus & +++ \\
\hline Vertical diagonal band of Broca & + \\
\hline Horizontal diagonal band of Broca & + \\
\hline Nucleus basalis magnocellularis & + \\
\hline \multicolumn{2}{|l|}{ Amygdala } \\
\hline Central amygdala & ++ \\
\hline Basolateral amygdala & ++ \\
\hline Medial amygdala & ++ \\
\hline Bed nucleus of the stria terminalis & ++ \\
\hline
\end{tabular}

,,+++++ or + denote strong, moderate, or low but positive signal, respectively.

entorhinal cortex. In the nucleus basalis magnocellularis, the intensity of the labeling was very low. The septofimbrial nucleus, the subfornical organ and the triangular septal nucleus showed intense $\mathrm{V}_{1 \mathrm{~b}} \mathrm{R}$ immunostaining. For all structures, perikarya and dendrites stainings were observed. However, in a few regions such as, for example, the frontal cortex, a dense $\mathrm{V}_{1 b} \mathrm{R}$ immunoreactivity was seen in the fibers.

\section{Behavioral Experiments}

Histological control. Slides stained with cresyl violet showed that the tip of the injection cannulae was located mostly in the medial part of the lateral septum (Figure 2). Rats were discarded from analysis when the lateral ventricle was damaged or when the implantation was outside the lateral septum. The final number of animals for the different groups were: Controls $N=10, \operatorname{SSR} 149415$ (1 ng) $N=8$, 

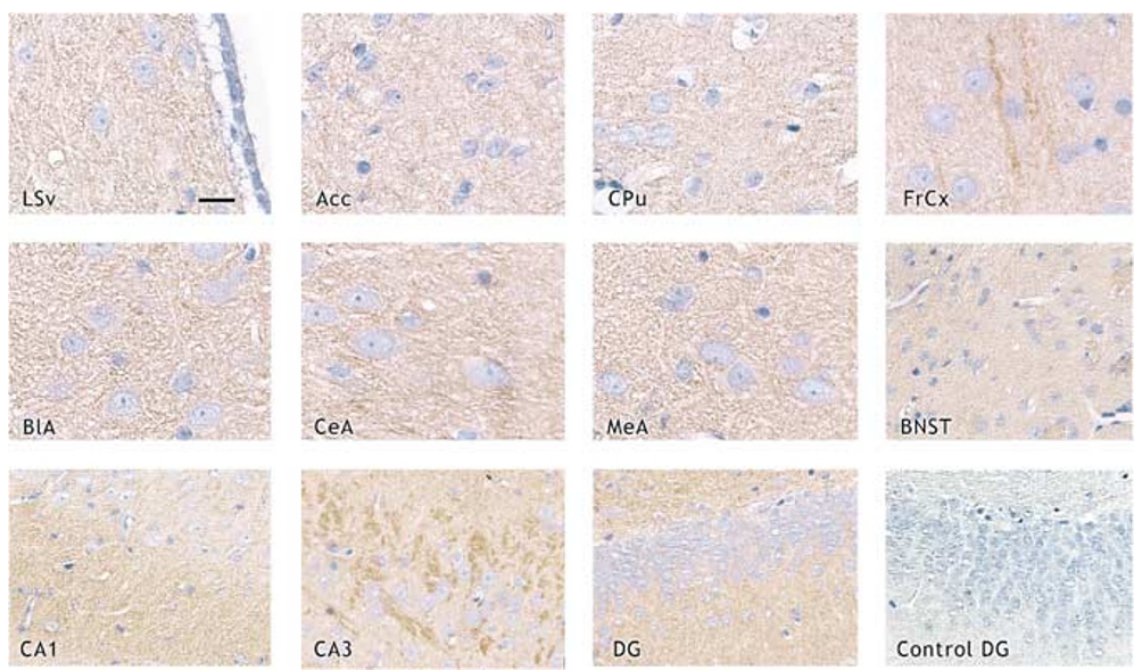

Figure I Localization of $V_{I b}$ receptors in the rat brain using anti $V_{I b} R$ immunohistochemistry. $V_{I b}-R$ signal is light brown and hematoxylin-stained nuclei are blue. LSv: ventral part of the lateral septum; Acc: accumbens shell nucleus; CPu: caudate putamen; FrCx: frontal cortex; BLA: basolateral amygdala; CeA: central amygdala; MeA: medial amygdala; BNST: bed nucleus of the stria terminalis; CAI-CA3: Ammon's horn fields; DG: dentate gyrus. Bar: I0 $\mu m$ except for BNST, CAI, CA3, DG $=15 \mu \mathrm{m}$

Table 2 Effects of Intraseptal SSRI494I 5 in the Punished Drinking and in the Elevated Plus-Maze Tests, and Intrastriatal SSRI494I 5 in the Forced-Swimming Test, in Rats

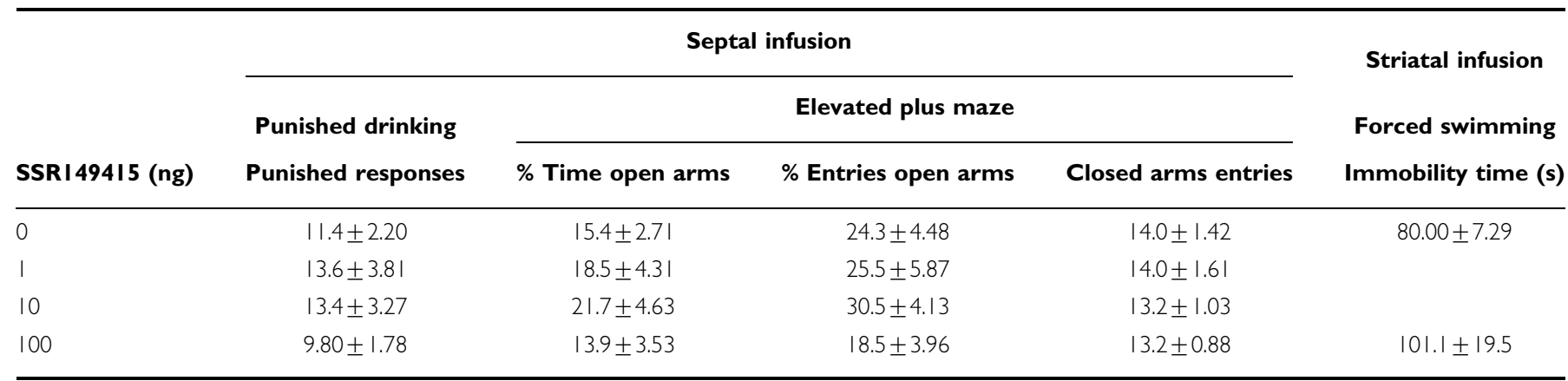

Data represent mean \pm SEM.

SSR149415 (10 ng) $N=10$, and SSR149415 (100 ng) $N=15$. For the striatal infusion experiment, all cannulae tips were located in the medial part of the caudate nucleus (not shown).

Behavioral controls. In order to verify that the DMSO and Cremophor combination was devoid of behavioral effects and, therefore, could be considered as a valid control, performances of saline-infused animals were compared to those of rats that received saline/DMSO/Cremophor. Results showed that there was no significant difference between the two control groups for each of the variables measured in the punished drinking test (number of shocks), elevated plus maze (\% time spent and \% entries in the open arms and number of entries in closed arms), and forced-swimming test (immobility time) (data not shown). As a result, the saline/DMSO/Cremophor combination was used as the control solution.

\section{Behavioral Testing}

Effects of intraseptal infusion of SSR149415 in the punished drinking test. The bilateral infusion of SSR149415 (1-100 ng) into the lateral septum did not modify significantly the number of punished responses $(\mathrm{F} 3,39=0.51, p=0.68$, see Table 2$)$.

Effects of intraseptal infusion of SSR149415 in the elevated plus-maze test. The bilateral infusion of SSR149415 into the lateral septum failed to modify the behaviors of animals in the elevated plus maze. ANOVA revealed that neither the indices of anxiety (ie the \% time spent or \% entries in the open arms) nor the presumed measure of activity was changed significantly after drug challenge (respectively, $\mathrm{F} 3,39=0.84, p=0.48 ; \mathrm{F} 3,39=1.35$, $p=0.27$, and $\mathrm{F} 3,39=0.13, p=0.94$, see Table 2 ).

Effects of intraseptal infusion of SSR149415 in the forcedswimming test. The bilateral infusion of SSR149415 into the lateral septum modified significantly immobility time $(\mathrm{F} 3,39=6.85, p<0.001)$. Post hoc comparisons showed that the doses of 10 and $100 \mathrm{ng}$ SSR149415 induced a significant reduction of this measure when compared to the saline/ DMSO/Cremophor control group $(p<0.05$ and $<0.01$, respectively). The lowest dose of SSR149415 (1 ng) tested was devoid of effects in this test (Figure 3). 


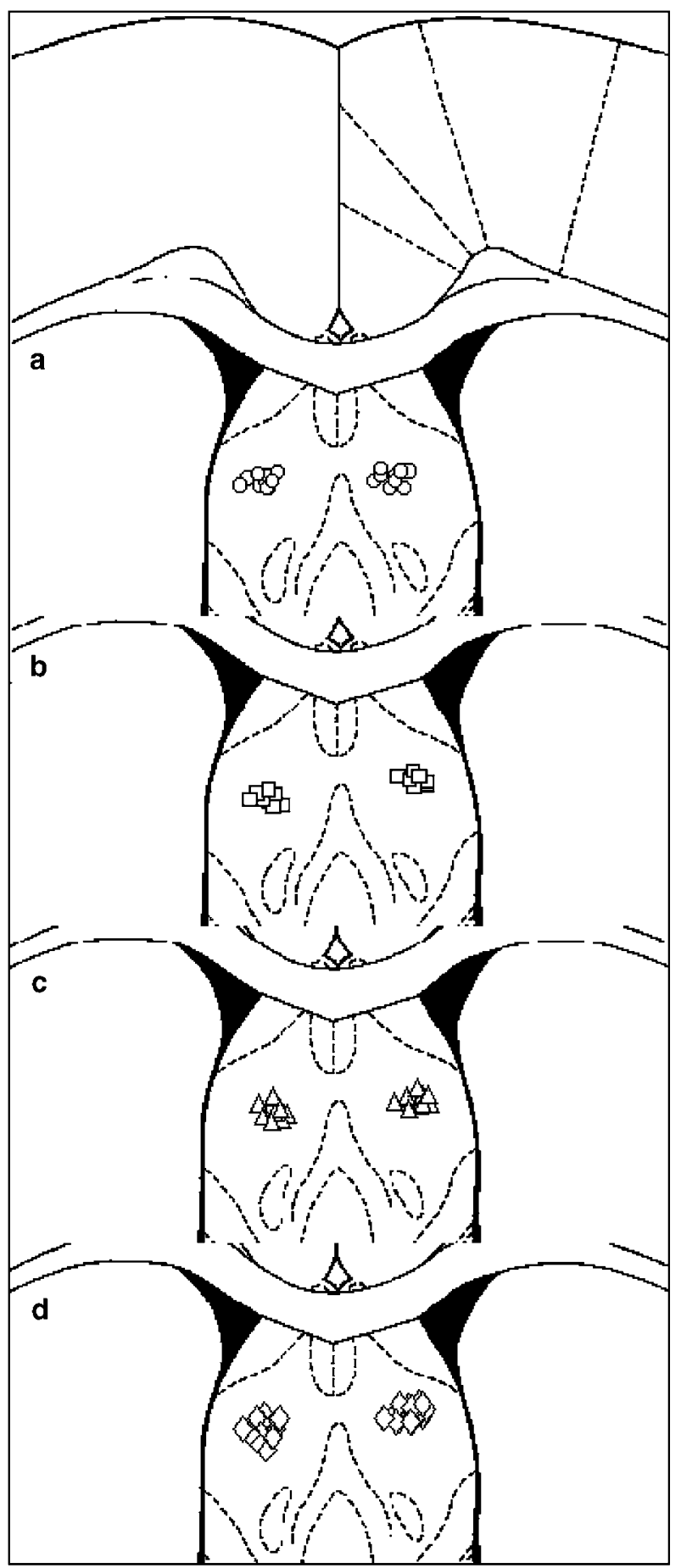

Figure 2 Schematic drawings of the localization of bilateral cannulae tips in the lateral septum of the rats treated with (a) control solution, (b) SSRI494I5 (I ng), (c) SSRI494I5 (I0 ng), or (d) SSRI494I5 (I00 ng), according to the rat brain atlas of Paxinos and Watson (1998). AP: $+0.2 \mathrm{~mm}$ from bregma.

Effect of bilateral infusion of SSR149415 into the medial striatum in the forced-swimming test. The infusion of a high dose of SSR149415 (100 ng) in the medial striatum did not modify significantly the behavior of animals in the forced-swimming test $(\mathrm{F} 1,14=0.83, p=0.38)$ (Table 2).

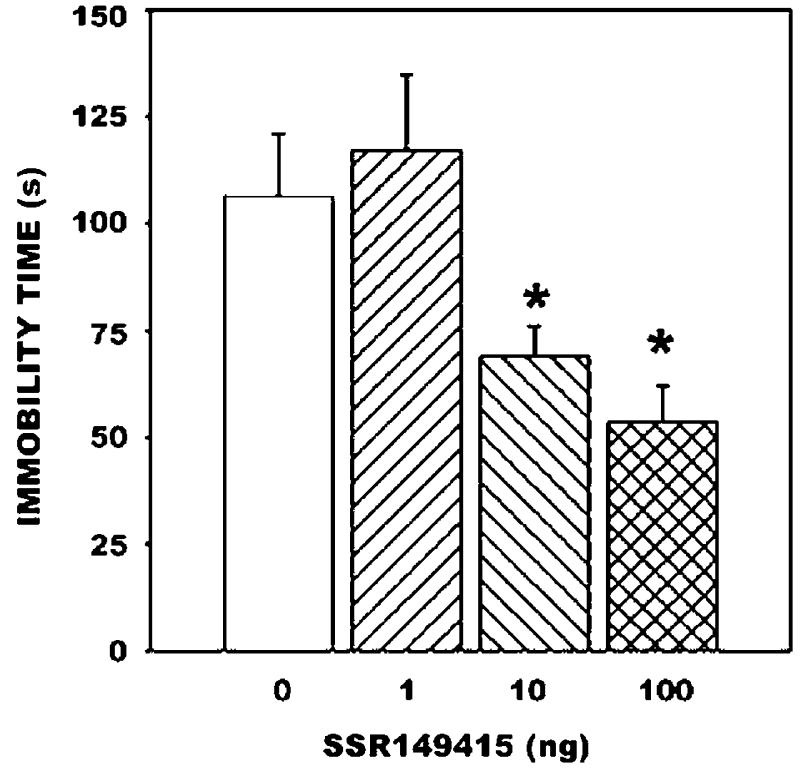

Figure 3 Effects of intraseptal SSRI 494I 5 in the forced-swimming test in rats. Data represent mean $\pm \mathrm{SEM} ; * p<0.05$ or less (Dunnett).

\section{DISCUSSION}

The first part of the present study described the localization of $\mathrm{V}_{1 \mathrm{~b}}$ receptors in the rat limbic brain using anti- $\mathrm{V}_{1 \mathrm{~b}}$ receptor immunohistochemistry. Results revealed that $\mathrm{V}_{1 \mathrm{~b}}$ receptors are present in the rat brain with a large distribution throughout the limbic system. In particular, a substantial amount of $\mathrm{V}_{1 \mathrm{~b}}$ receptors was detected in the lateral septum, the hippocampus, the amygdaloid region and the cortex. Second, we assessed the behavioral effects of local infusion of SSR149415 in the lateral septum, a region involved in stress-related behaviors. The behavioral experiments showed that local infusion of SSR149415 in the lateral septal area induced clearcut and dose-dependent antidepressant-like effects in the forced-swimming test, while similar treatment did not modify anxiety-related behaviors in the punished drinking and elevated plus-maze tests.

To date only a few studies have examined the expression of $\mathrm{V}_{1 \mathrm{~b}}$ receptor mRNA or protein in the rat brain (Lolait et al, 1995; Vaccari et al, 1998; Hernando et al, 2001). Using RT-PCR, Lolait et al (1995) provided the first evidence of extrapituitary $\mathrm{V}_{1 \mathrm{~b}}$ receptor mRNA expression in the rat brain tissues. Together with other authors (Vaccari et al, 1998; Hernando et al, 2001), they showed that $V_{1 b}$ receptors are present in the central nervous system, including the basal ganglia, septohippocampal and several cortical regions. In the present study, using a new anti- $\mathrm{V}_{1 \mathrm{~b}}$ receptor antibody, we detected the presence of $\mathrm{V}_{1 \mathrm{~b}}$ receptors in additional regions of the limbic system such as the diagonal band of Broca, all the regions of the hippocampal formation (fields of the Ammon's horn, dentate gyrus, subiculum and entorhinal cortex), the central, medial, and basolateral amygdaloid nuclei, and the bed nucleus of the stria terminalis. Our results clearly indicate that $\mathrm{V}_{1 \mathrm{~b}}$ receptors are largely distributed outside the hypothalamic regions of the rat brain. This suggests that vasopressin, through $\mathrm{V}_{1 \mathrm{~b}}$ receptors, may play an important modulatory role in limbic 
functioning, reinforcing the idea that the peptide is involved in stress-related behaviors, and that $\mathrm{V}_{1 \mathrm{~b}}$ receptors probably mediate its effects. Hopefully, the availability of selective $\mathrm{V}_{1 \mathrm{~b}}$ receptor radioligands will certainly help to obtain a more complete picture of the distribution of $\mathrm{V}_{1 \mathrm{~b}}$ receptors throughout the central nervous system. In addition, ultrastructural studies are required to determine whether $\mathrm{V}_{1 \mathrm{~b}}$ receptors are distributed on pre- or postsynaptic membranes. This will help to better understand the regulatory role vasopressin exerts on synaptic transmission.

The behavioral experiments aimed at determining a possible site of action of the antistress-like effects of the selective nonpeptide $V_{1 b}$ receptor antagonist, SSR149415. A previous report (Griebel et al, 2002) has indicated that the antidepressant-like effects of SSR149415 do not only involve the blockade of $\mathrm{V}_{1 \mathrm{~b}}$ receptors of the hypothalamus since these effects were still observed in hypophysectomized rats. Here, SSR149415 was directly infused into the lateral septum, a brain structure enriched in $V_{1 b}$ receptors as evidenced by the current immunohistochemistry data. Moreover, as indicated above, the lateral septum plays a key role in the modulation of emotional behaviors. Results showed that intraseptal application of SSR149415 elicited antidepressant- but not anxiolytic-like effects. The decrease in immobility in the forced-swimming test may be indicative of an antidepressant-like action of the drug. However, one cannot totally rule out the possibility that this effect may be the consequence of a nonspecific (ie motor) action of the drug. Data from the elevated plus-maze on closed arms entries may shed some light on this issue since this presumed index of locomotor activity was not changed over the entire dose-range tested (1-100 ng). Moreover, when administered systematically, SSR149415 did not modify several locomotor parameters assessed in different behavioral tests such as line crossings in the defense battery (Griebel et al, 2002) or swimming abilities in the Morris water maze task observed after repeated administrations of the drug as was the case here (Griebel et al, 2003), suggesting that the $\mathrm{V}_{1 \mathrm{~b}}$ receptor antagonist was devoid of central effects not related to emotionality. Although a leakage of the infused solution to adjacent brain areas (bed nucleus of the stria terminalis for instance) cannot be excluded, it is unlikely that the antidepressant-like effects of SSR149415 are due to the blockade of $\mathrm{V}_{1 \mathrm{~b}}$ receptors located in other structures since the volume injected in the lateral septum was rather small $(0.3 \mu \mathrm{l})$. Moreover, a ventricular contamination or diffusion through the tissue is unlikely as the infusion of the compound into the striatum, a nearby structure, was devoid of any antidepressant-like effect. This latter result also suggests that $\mathrm{V}_{1 \mathrm{~b}}$ receptors present in the striatum (see immmunohistochemistry data of the present study) are not involved the antidepressant-like effects of SSR149415. It is noteworthy that the clear reduction in immobility time in the forced-swimming test following intraseptal infusion of SSR149415 paralleled that observed after systemic administration of the compound (Griebel et al, 2002), suggesting that $\mathrm{V}_{1 \mathrm{~b}}$ receptors located in the lateral septum play a key role in the mediation of the antidepressant-like effects of SSR149415 in rats. However, these effects do not fit well with those described in another study (Ebner et al, 1999), where increases in floating time were observed after intraseptal infusion of the mixed $V_{1 a / 1 b}$ peptide antagonist $\mathrm{d}\left(\mathrm{CH}_{2}\right)_{5} \mathrm{Tyr}(\mathrm{Me}) \mathrm{AVP}$ using a retrodialysis technique in rats. The discrepancies between our results and those of Ebner could be explained by differences in both the administration (microinjection $v s$ retrodialysis) and the testing (single $v s$ test-retest) procedures, which could have differentially affected vasopressinergic tone and the subsequent effects of the blockade of the vasopressinergic transmission. Another explanation could be that the behavioral effects induced by the mixed peptide antagonist resulted in the preferential blockade of the $V_{1 a}$ receptor subtype, which may exert an opposite action of that of the $\mathrm{V}_{1 \mathrm{~b}}$ subtype. To illustrate this idea, a recent study using knockout mice for either $\mathrm{V}_{1 \mathrm{~b}}$ or $\mathrm{V}_{1 \mathrm{a}}$ receptors on social aggression showed that aggression was decreased in $\mathrm{V}_{1 \mathrm{~b}}^{-1-}$ mice, while it was increased in $\mathrm{V}_{1 \mathrm{a}}^{-1-}$ mice (Wersinger et al, 2003). Altogether, these results suggest opposite roles for $\mathrm{V}_{1 \mathrm{~b}}$ and $\mathrm{V}_{1 \mathrm{a}}$ receptors in the mediation of behavioral responses, reinforcing the idea that the blockade of $V_{1 b}$ receptors may be relevant for the treatment of stress-related disorders. Although our results on the antidepressant-like effects of intraseptal SSR149415 reproduce those obtained in a previous experiment using systemic administration, they do not exclude that $V_{1 b}$ receptors located in other limbic regions, such as, for example, the amygdala, may also participate in the action of the $\mathrm{V}_{1 \mathrm{~b}}$ antagonist. It has been demonstrated that the intra-amygdala delivery of the mixed $\mathrm{V}_{1 \mathrm{a} / 1 \mathrm{~b}}$ peptide antagonist $\mathrm{d}\left(\mathrm{CH}_{2}\right)_{5} \mathrm{Tyr}(\mathrm{Me}) \mathrm{AVP}$ by using a retrodialysis technique may modify stress-coping strategies in a swim test (Ebner et al, 2002). The present study revealed that intraseptal infusion of SSR149415 had no effect on anxiety-related behaviors as measured in the punished drinking and elevated plus-maze tests. In previous studies, anxiolytic effects of systemic administration of SSR149415 were described in the punished drinking and the elevated plus-maze tests, although the effects of the compound were weaker than those observed with the benzodiazepine anxiolytic diazepam (Griebel et al, 2002). Although it is recognized that the activity of the lateral septum mediates anxiety-related behaviors in tests based on exploration or conflict situations (Treit and Menard, 2000), septal $\mathrm{V}_{1 \mathrm{~b}}$ receptors may not be involved in the mediation of anxiolytic-like effects of SSR149415. We demonstrated that other structures such as the different amygdaloid nuclei contain $\mathrm{V}_{1 \mathrm{~b}}$ receptors. These brain areas are also known to mediate anxiety-related behaviors observed in the elevated plus-maze or in the punished drinking test (Graeff et al, 1993), suggesting that $V_{1 b}$ receptor located in the amygdala may mediate the anxiolytic effects of SSR149415.

In conclusion, this study demonstrated that the blockade of septal $\mathrm{V}_{1 \mathrm{~b}}$ receptors with SSR149415 induced robust antidepressant-like effects resembling those observed after systemic administration of the compound. However, the brain region involved in the mediation of the anxiolytic-like action of SSR149415 remains to be determined.

\section{ACKNOWLEDGEMENTS}

We would like to acknowledge M L'Hermitte, C Aliaga, N Moindrot for technical assistance on behavioral studies and D Duverger and B Piveux for advising on perfusion and paraffin embedding. 


\section{REFERENCES}

Aguilera G, Rabadan-Diehl C (2000). Vasopressinergic regulation of the hypothalamic-pituitary-adrenal axis: implications for stress adaptation. Regul Peptides 96: 23-29.

Caffe AR, van Leeuwen FW, Luiten PG (1987). Vasopressin cells in the medial amygdala of the rat project to the lateral septum and ventral hippocampus. J Comp Neurol 261: 237-252.

Contreras CM, Lara-Morales H, Molina-Hernandez M, Saavedra M, Arrellin-Rosas G (1995). An early lesion of the lateral septal nuclei produces changes in the forced swim test depending on gender. Prog Neuropsychopharmacol Biol Psychiatry 19: 12771284.

Dantzer R, Koob GF, Bluthe RM, Le Moal M (1988). Septal vasopressin modulates social memory in male rats. Brain Res 457: 143-147.

De Vries GJ, Buijs RM (1983). The origin of the vasopressinergic and oxytocinergic innervation of the rat brain with special reference to the lateral septum. Brain Res 273: 307-317.

Ebner K, Wotjak CT, Holsboer F, Landgraf R, Engelmann M (1999). Vasopressin released within the septal brain area during swim stress modulates the behavioural stress response in rats. Eur J Neurosci 11: 997-1002.

Ebner K, Wotjak CT, Landgraf R, Engelmann M (2002). Forced swimming triggers vasopressin release within the amygdala to modulate stress-coping strategies in rats. Eur J Neurosci 15: 384388.

Estrada-Camarena E, Contreras CM, Saavedra M, Luna-Baltazar I, Lopez-Rubalcava C (2002). Participation of the lateral septal nuclei (LSN) in the antidepressant-like actions of progesterone in the forced swimming test (FST). Behav Brain Res 134: 175183.

Everts HG, De Ruiter AJ, Koolhaas JM (1997). Differential lateral septal vasopressin in wild-type rats: correlation with aggression. Horm Behav 31: 136-144.

Folny V, Raufaste D, Lukovic L, Pouzet B, Rochard P, Pascal M et al (2003). Pancreatic vasopressin $V_{1 b}$ receptors: characterization in In-R1-G9 cells and localization in human pancreas. Am J Physiol Endocrinol Metab 285: E566-E576.

Graeff FG, Silveira MC, Nogueira RL, Audi EA, Oliveira RM (1993). Role of the amygdala and periaqueductal gray in anxiety and panic. Behav Brain Res 58: 123-131.

Griebel G, Simiand J, Serradeil-Le Gal C, Wagnon J, Pascal M, Scatton B et al (2002). Anxiolytic- and antidepressant-like effects of the non-peptide vasopressin $\mathrm{V}_{1 \mathrm{~b}}$ receptor antagonist, SSR149415, suggest an innovative approach for the treatment of stress-related disorders. Proc Natl Acad Sci USA 99: 63706375.

Griebel G, Simiand J, Stemmelin J, Serradeil-Le Gal C, Steinberg R (2003). The vasopressin $V_{1 b}$ receptor as a therapeutic target in stress-related disorders. Curr Drug Target CNS Neurol Disord 2: 191-200.

Hernando F, Schoots O, Lolait SJ, Burbach JP (2001). Immunohistochemical localization of the vasopressin $\mathrm{V}_{1 \mathrm{~b}}$ receptor in the rat brain and pituitary gland: anatomical support for its involvement in the central effects of vasopressin. Endocrinology 142: $1659-1668$.

Hurbin A, Orcel H, Alonso G, Moos F, Rabie A (2002). The vasopressin receptors colocalize with vasopressin in the magnocellular neurons of the rat supraoptic nucleus and are modulated by water balance. Endocrinology 143: 456-466.

Landgraf R, Gerstberger R, Montkowski A, Probst JC, Wotjak CT, Holsboer $\mathrm{F}$ et al (1995). $\mathrm{V}_{1}$ vasopressin receptor antisense oligodeoxynucleotide into septum reduces vasopressin binding, social discrimination abilities, and anxiety-related behavior in rats. J Neurosci 15: 4250-4258.

Liebsch G, Wotjak CT, Landgraf R, Engelmann M (1996). Septal vasopressin modulates anxiety-related behaviour in rats. Neurosci Lett 217: 101-104.

Lolait SJ, O'Carroll AM, Mahan LC, Felder CC, Button DC, Young III WS et al (1995). Extrapituitary expression of the rat $\mathrm{V}_{1 \mathrm{~b}}$ vasopressin receptor gene. Proc Natl Acad Sci USA 92: 67836787.

Paxinos G, Watson W (1998). The Rat Brain in Stereotaxic Coordinates, 4th edn. Academic Press: London.

Pellow S, Chopin P, File SE, Briley M (1985). Validation of open:closed arm entries in an elevated plus-maze as a measure of anxiety in the rat. J Neurosci Methods 14: 149-167.

Pesold C, Treit D (1994). The septum and amygdala differentially mediate the anxiolytic effects of benzodiazepines. Brain Res 638 : 295-301.

Porsolt R, Le Pichon M, Jalfre M (1977). Depression: a new animal model sensitive to antidepressant treatments. Nature 266: 730732.

Rabadan-Diehl C, Makara G, Kiss A, Lolait S, Zelena D, Ochedalski $\mathrm{T}$ et al (1997). Regulation of pituitary $\mathrm{V}_{1 \mathrm{~b}}$ vasopressin receptor messenger ribonucleic acid by adrenalectomy and glucocorticoid administration. Endocrinology 138: 5189-5194.

Schreiber R, De Vry J (1993). Neuroanatomical basis for the antidepressant-like effects of the 5-HT(1A) receptor agonists 8$\mathrm{OH}-\mathrm{DPAT}$ and ipsapirone in the rat forced swimming test. Behav Pharmacol 4: 625-636.

Serradeil-Le Gal C, Wagnon J, Simiand J, Griebel G, Lacour C, Guillon $\mathrm{G}$ et al (2002). Characterization of $(2 S, 4 R)$-1-[5-chloro-1[(2,4-dimethoxyphenyl)sulfonyl]-3-(2-methoxy-phenyl)-2-oxo2,3-dihydro- $1 H$-indol-3-yl]-4-hydroxy- $N, N$-dimethyl-2-pyrrolidine carboxamide (SSR149415), a selective and orally active vasopressin $\mathrm{V}_{1 \mathrm{~b}}$ receptor antagonist. J Pharmacol Exp Ther 300: $1122-1130$.

Treit D, Menard J (2000). The septum and anxiety. In: Numan R (ed). The Behavioural Neuroscience of the Septal Region. Springer-Verlag: New York, pp 210-233.

Treit D, Pesold C (1990). Septal lesions inhibit fear reactions in two animal models of anxiolytic drug action. Physiol Behav 47: 365371.

Vaccari C, Lolait SJ, Ostrowski NL (1998). Comparative distribution of vasopressin $\mathrm{V}_{1 \mathrm{~b}}$ and oxytocin receptor messenger ribonucleic acids in brain. Endocrinology 139: 5015-5033.

Vogel JR, Beer B, Clody DE (1971). A simple and reliable conflict procedure for testing anti-anxiety agents. Psychopharmacologia 21: $1-7$.

Wersinger SR, Christiansen M, O'Carroll A, Lolait SJ, Gold PW, Hu $S$ et al (2003). Social aggression is reduced in vasopressin $1 \mathrm{~b}$ receptor null mice but is elevated in vasopressin 1a receptor null mice. Program No. 838.14. 2003 Abstract Viewer/Itinerary Planner. Society for Neuroscience: Washington, DC.

Yadin E, Thomas E, Grishkat HL, Strickland CE (1993). The role of the lateral septum in anxiolysis. Physiol Behav 53: 1077-1083. 